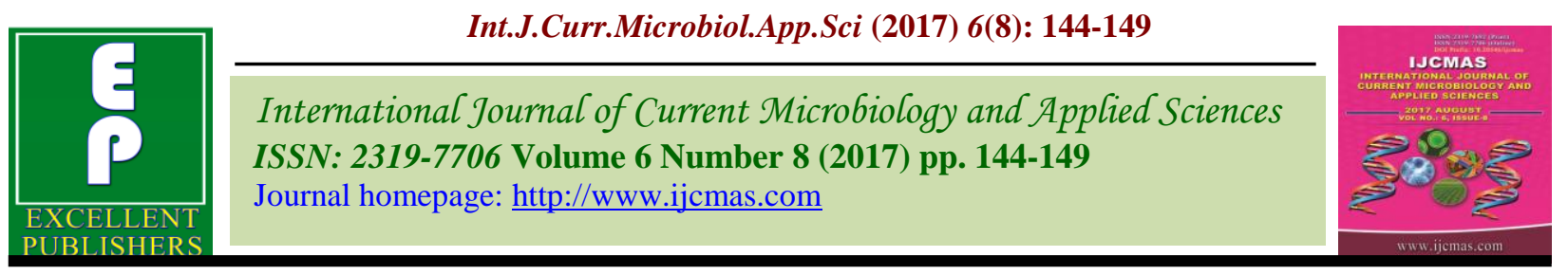

Original Research Article

https://doi.org/10.20546/ijcmas.2017.608.020

\title{
Growth, Yield and Quality of Onion (Allium cepa L.) as Influenced by Organic Farming Practices
}

\author{
M. Prabhakar, S.S. Hebbar, A.K. Nair*, P. Panneer Selvam, \\ R.S. Rajeshwari and Praveen Kumar
}

\author{
Division of Vegetable Crops, ICAR-Indian Institute of Horticultural Research, \\ Hesaraghatta Lake P.O., Bangalore, Karnataka-560089, India \\ *Corresponding author
}

\author{
A B S T R A C T
}

\begin{tabular}{|l|}
\hline Ke y w or d s \\
Onion, Farm yard \\
manure, Organic \\
farming, Chemical \\
fertilizers, Growth, \\
Dry matter, Yield \\
and quality.
\end{tabular}

A field experiment was conducted during Rabi seasons of 2012 and 2013 at fixed organic experimental plot of ICAR-India Institute of Horticultural Research farm, Hesaraghatta, Bengaluru to study the effect of different levels of farm yard manure (FYM) in organic as compared to chemical and conventional practices on growth, yield and quality of onion. The trial included five levels of farm yard manure and two inorganic nutrient supply treatments consisting of only chemical treatment (NPK fertilizers + chemical plant protection) and conventional practice (Recommended dose of FYM + NPK fertilizers + chemical plant protection). Conventional treatment recorded highest plant height $(50.1 \mathrm{~cm})$ as well as bulb yield (34.8 t/ha), while onion crop which had received organic manure equivalent to 100 per cent recommended dose of nitrogen (RDN) recorded highest number of leaves (10.5) per plant. This bulb yield was on par with the yields obtained in organic treatments receiving FYM equivalent to 50 to 100 per cent RDN. The lower bulb yields were with organic treatment receiving manures equivalent to 25 per cent RDN and treatment receiving only NPK fertilizers. There were no marked differences among the treatments for the quality parameters such as bulb dry matter and shelf life.

\section{Introduction}

Organic cultivation offers one of the most sustainable farming systems with recurring benefits not only in long term soil health but also in providing stability in production by imparting better resistance against various biotic and abiotic stresses. Consumer demand for organically grown vegetables is steadily increasing all over the world for both domestic and export market. This drastic change is due to human concern over health which made him to produce pesticide residue and other harmful chemicals-free crops. The challenges are how to produce these crops in ways that are environmentally friendly and without lowering the yield levels achieved by conventional production systems (Prabhakar et al., 2012). Organic vegetables fetch a premium price of 10 to 50 per cent over conventional products (Sridhar et al., 2014) making it attractive proposition for the selective farmers interested in this. Onion (Allium cepa L.) is one of the important commercial bulbous crops cultivated extensively in India covering an area of 1.203 million hectares with a production of 19.401 million tonnes and productivity of 16.10 tonnes per hectare (NHB, 2014). Onions are classified as dry (bulb) or green (spring 
onion). Bulb onion varieties are generally classified by day-length (short, intermediate, long day types), market use (fresh bulb, dehydrator bulb or storage type) and bulb color within the fresh market class (white, yellow, light red, red and dark red). Since onion is consumed as fresh vegetable, used in processing and pickling and also the lead export vegetable from India, developing organic production protocols is highly relevant in the present context.

\section{Materials and Methods}

The field trials on organic onion were carried out at ICAR-Indian Institute of Horticultural Research, Bengaluru during rabi seasons of 2012 and 2013. The soil of experimental plot was well drained sandy loam with $\mathrm{pH} 7.29$ and EC $0.22 \mathrm{dS} / \mathrm{m}$. The initial soil organic carbon content was in the range of 0.56 to $0.86 \%$. The available $\mathrm{N}, \mathrm{P}_{2} \mathrm{O}_{5}$ and $\mathrm{K}_{2} \mathrm{O}$ were in the range of 186.0-209.0, 21.0- 38.0 and 168.0-207.0 kg/ha, respectively. The experiment was carried out in a Randomized Block Design with three replications. Organic and inorganic plots were situated five meter apart from each other and separated by a Glyricidia sp. live hedge to protect from possible spray drift to organic treatments.

The experiment consisted of seven treatments, viz., $\mathrm{T}_{1}: 100 \%, \mathrm{~T}_{2}: 75 \%, \mathrm{~T}_{3}: 50 \%, \mathrm{~T}_{4}: 25 \%$ of recommended dose of nitrogen equivalent to farm yard manure (FYM) application. $\mathrm{T}_{5}$ : only recommended FYM @ 25 t/ha, $\mathrm{T}_{6}$ : chemical treatment receiving only recommended $\mathrm{N} P \mathrm{~K}$ fertilizers and $\mathrm{T}_{7}$ : Conventional practice (recommended FYM ( $25 \mathrm{t} / \mathrm{ha}+$ recommended N P K fertilizers). The treatments under organic cultivation received well decomposed FYM as source of nutrients prior to transplanting. Quantity of FYM required for different treatments was calculated based on dry weight and total nitrogen content of manure used. The recommended dose of fertilizers for onion crop i.e. $125: 50: 125 \mathrm{~kg}$ per hectare of $\mathrm{N}$ : $\mathrm{P}_{2} \mathrm{O}_{5}: \quad \mathrm{K}_{2} \mathrm{O}$ was adopted. In $\mathrm{T}_{6}$ and $\mathrm{T}_{7}$ treatments entire amount of $\mathrm{P}$ was applied as basal dose and $\mathrm{N}$ and $\mathrm{K}$ were applied in two equal splits, one at the time of planting and the other as side dress given after 30 days of planting. Farm yard manure applied in organic treatments was enriched with biofertilizers and bio-agents like Azospirillum, phosphate solubilizing bacteria (PSB), Pseudomonas fluorescens and Trichoderma harzianum before field application each at the rate of $2.5 \mathrm{~kg}$ per hectare. Supplemental $\mathrm{P}$ was given through PSB treated rock phosphate @ $50 \mathrm{~kg} / \mathrm{ha} /$ year and neem cake was also added @ $625 \mathrm{~kg} / \mathrm{ha}$.

Forty days old seedlings of onion variety Arka Niketan were transplanted during second week of November in both the years at a spacing of $20 \mathrm{~cm} \times 10 \mathrm{~cm}$. The crop was irrigated with inline drip system having the discharge rate of 4 liter per hour to supply irrigation@ 0.8 Epan losses. Organic plant protection was taken up using Trichoderma harzianum, Beauveria basiana, Verticillium lecani, neem seed powder extract (4\%), neem, pongamia soap $(0.7 \%)$ and bordeaux mixture (1\%) for management of alternaria, basal rot and thrips mainly. For $\mathrm{T}_{6}$ and $\mathrm{T}_{7}$, recommended plant protection chemicals were used. The harvesting of the crop was done at 120 days after transplanting. The observations on crop growth, yield parameters and bulb quality were recorded and data was statistically analyzed as adopted by Gomez and Gomez (1983).

\section{Results and Discussion}

\section{Effect on growth parameters}

The results obtained from the response of onion to application of organic nutrients with respect to growth parameters are presented in 
table 1 as pooled analysis data of two years. Effect of organic treatments on growth parameters with reference to number of leaves in onion exhibited significant differences, while it remained non-significant for plant height. It can be seen that the conventional treatment $\mathrm{T}_{7}$ recorded numerically highest plant height $(50.1 \mathrm{~cm})$ than remaining treatments. Within the organic nutrient supply treatments, higher plant height $(46.1 \mathrm{~cm})$ was observed with $\mathrm{T}_{1}$, where highest amount of FYM equivalent to $100 \%$ of recommended $\mathrm{N}$ was applied.

Similarly the treatment $\mathrm{T}_{1}$ has resulted in significantly highest number of leaves per plant (10.5) than all other treatments, while the chemical treatment $\mathrm{T}_{6}$ (recommended NPK fertilizers only) recorded lowest number of leaves (8.9). The plant height and number of leaves were found to decrease with decrease in amount of FYM given in organic treatments.

The increase in plant growth parameters with higher application of organic sources can be attributed to supply of higher amounts of N, P and $\mathrm{K}$ besides making unavailable sources of elemental nitrogen, bound phosphates and micronutrients from decomposed plant residues into available form, thereby facilitating the plants to absorb these nutrients.

This may be also due to better plant root development by virtue of improved aeration in soil. These are in agreement with the findings of Mamatha (2006), Sofia et al., (2006) and Yadav et al., (2013) in onion crop.

\section{Effect on yield and quality attributes}

The pooled data on onion bulb yield parameters and yield are presented in table 1 . Though organic and inorganic treatments tested did not result in significant differences with respect to mean fresh bulb weight, higher values were recorded in conventional treatment $\mathrm{T}_{7}(103.5 \mathrm{~g})$ followed by organic treatments $\mathrm{T}_{1}(100.9 \mathrm{~g})$. The lowest bulb weight of $94.4 \mathrm{~g}$ was observed with chemical treatments receiving only chemical fertilizers. The conventional treatment $\mathrm{T}_{7}$ recorded significantly highest bulb yield (34.81 t/ha) followed by the treatment $T_{1}$ which received organic manure equivalent to 100 per cent of RDN (32.88 t/ha). The lower bulb yield of $29.94 \mathrm{t} / \mathrm{ha}$ and $29.13 \mathrm{t} / \mathrm{ha}$ were recorded in treatments $\mathrm{T}_{4}$ (organic treatment receiving FYM equivalent to 25 per cent of RDN) and $\mathrm{T}_{6}$ (chemical treatment receiving only chemical fertilizers). Higher yields per hectare in $T_{1}$ and $T_{7}$ treatments were mainly due to higher bulb weight. This is in agreement with the findings of Lal et al., (2002) who reported that increase rates of organic manure application resulted in higher bulb size and bulb yield of onion.

Quality attributes such as bulb dry matter content (\%) and total soluble solids (TSS ${ }^{\circ} \mathrm{B}$ ) recorded are also presented in table 1 . Though there were no significant differences among organic and inorganic treatments tested with respect to these parameters the values were marginally superior in conventional treatment and the organic treatments receiving higher quantities of organic manures. These results are in line with the findings of Yassen and Khalid (2009) and Pradeep and Sharanappa, (2014) in organically grown onion crop.

The data pertaining to storage studies in Arka Niketan onion bulbs presented in table 2 . Irrespective of nutrition levels, fresh weight of bulbs stored up to ninety days showed a very marginal loss in weight in the range of 9.2- 15.5 per cent. However, the loss in weight was comparatively low in organic treatments indicating improvement in storage life of bulbs with organic cultivation. 
Table.1 Growth, yield and bulb quality in onion as influenced by source and quantity of manures and fertilizers (pooled data)

\begin{tabular}{|c|c|c|c|c|c|c|}
\hline Treatment & $\begin{array}{c}\text { Plant } \\
\text { height } \\
(\mathbf{c m})\end{array}$ & $\begin{array}{c}\text { No. of } \\
\text { leaves/ } \\
\text { plant }\end{array}$ & $\begin{array}{c}\text { Bulb dry } \\
\text { matter } \\
\text { content }(\boldsymbol{\%})\end{array}$ & $\begin{array}{c}\text { TSS } \\
\left({ }^{\mathbf{0}} \mathbf{B}\right)\end{array}$ & $\begin{array}{c}\text { Bulb } \\
\text { weight } \\
(\mathbf{g})\end{array}$ & $\begin{array}{c}\text { Bulb yield } \\
(\mathbf{t} / \mathbf{h a})\end{array}$ \\
\hline $\mathrm{T}_{1}$ & 46.1 & 10.5 & 13.8 & 13.2 & 100.9 & 32.88 \\
\hline $\mathrm{T}_{2}$ & 45.9 & 10.0 & 12.6 & 12.2 & 98.8 & 32.40 \\
\hline $\mathrm{T}_{3}$ & 45.3 & 9.9 & 13.5 & 12.8 & 96.2 & 31.60 \\
\hline $\mathrm{T}_{4}$ & 43.9 & 9.7 & 13.6 & 12.9 & 94.9 & 29.94 \\
\hline $\mathrm{T}_{5}$ & 45.2 & 9.9 & 13.1 & 12.7 & 96.1 & 31.46 \\
\hline $\mathrm{T}_{6}$ & 44.9 & 8.9 & 14.6 & 13.7 & 94.4 & 29.13 \\
\hline $\mathrm{T}_{7}$ & 50.1 & 10.2 & 14.3 & 13.5 & 103.5 & 34.81 \\
\hline C.D @ 5\% & $\mathrm{NS}$ & 0.53 & $\mathrm{NS}$ & $\mathrm{NS}$ & $\mathrm{NS}$ & 3.23 \\
\hline
\end{tabular}

\section{Treatment details}

$\mathrm{T}_{1}$ : $\quad$ FYM equivalent to $100 \% \mathrm{RDN}$

$\mathrm{T}_{5}: \quad$ Only recommended FYM @ 25 t/ha

$\mathrm{T}_{2}$ : $\quad \mathrm{FYM}$ equivalent to $75 \% \mathrm{RDN}$

$\mathrm{T}_{6}$ : $\quad$ Recommended NPK fertilizers only

$\mathrm{T}_{3}$ : $\quad$ FYM equivalent to $50 \% \mathrm{RDN}$

$\mathrm{T}_{7}$ : Conventional practice (recommended FYM+NPK fertilizers)

$\mathrm{T}_{4}$ : $\quad \mathrm{FYM}$ equivalent to $25 \% \mathrm{RDN}$

Table.2 Storage studies in onion (10 bulbs) as influenced by organic manures and fertilizers (pooled data)

\begin{tabular}{|c|c|c|c|c|}
\hline Treatment & $\begin{array}{c}\text { Fresh wt. of bulbs } \\
\text { at harvest }(\mathbf{g})\end{array}$ & $\begin{array}{c}\text { Air dry wt. after } \\
\text { 30 days }(\mathbf{g})\end{array}$ & $\begin{array}{c}\text { Air dry wt. after } \\
\text { 60 days }(\mathbf{g})\end{array}$ & $\begin{array}{c}\text { Air dry wt. after } \\
\text { 90 days }(\mathbf{g})\end{array}$ \\
\hline $\mathrm{T}_{1}$ & 1009 & $945(6.3)$ & $916(9.2)$ & $902(10.6)$ \\
\hline $\mathrm{T}_{2}$ & 988 & $919(7.0)$ & $906(8.3)$ & $900(9.6)$ \\
\hline $\mathrm{T}_{3}$ & 962 & $928(3.7)$ & $902(6.2)$ & $873(9.2)$ \\
\hline $\mathrm{T}_{4}$ & 989 & $923(6.6)$ & $902(8.8)$ & $878(11.2)$ \\
\hline $\mathrm{T}_{5}$ & 1012 & $949(6.2)$ & $915(9.5)$ & $855(15.5)$ \\
\hline $\mathrm{T}_{6}$ & 931 & $870(6.5)$ & $833(10.5)$ & $813(12.6)$ \\
\hline $\mathrm{T}_{7}$ & 1035 & $974(5.9)$ & $939(9.3)$ & $901(12.0)$ \\
\hline C.D@ $5 \%$ & $\mathrm{NS}$ & $\mathrm{NS}$ & $\mathrm{NS}$ & $\mathrm{NS}$ \\
\hline
\end{tabular}

* - Figures in the parenthesis indicates percentage reduction

Table.3 Chemical and microbial properties of experiment plot soils

\begin{tabular}{|c|c|c|c|c|c|}
\hline Treatment & pH & $\begin{array}{c}\mathrm{EC} \\
(\mathrm{dS} / \mathrm{m})\end{array}$ & $\begin{array}{l}\mathrm{OC} \\
(\%)\end{array}$ & $\begin{array}{c}\text { Soil respiration } \\
\text { (C mg/kg/ha) }\end{array}$ & $\begin{array}{l}\text { Dehydrogenase activity ( } \mu \mathrm{g} \text { of } \\
\text { TPF released } \mathrm{g}^{-1} \text { of soil/ha) }\end{array}$ \\
\hline $\mathrm{T}_{1}$ & 7.67 & 0.19 & 1.33 & 9.43 & 122.50 \\
\hline $\mathrm{T}_{2}$ & 7.57 & 0.18 & 1.35 & 9.47 & 125.57 \\
\hline $\mathrm{T}_{3}$ & 7.56 & 0.21 & 0.93 & 9.07 & 115.57 \\
\hline $\mathrm{T}_{4}$ & 7.26 & 0.16 & 1.30 & 7.83 & 99.60 \\
\hline $\mathrm{T}_{5}$ & 7.63 & 0.17 & 0.97 & 7.23 & 98.80 \\
\hline $\mathrm{T}_{6}$ & 7.48 & 0.33 & 0.70 & 6.77 & 85.20 \\
\hline $\mathrm{T}_{7}$ & 7.54 & 0.28 & 0.86 & 7.05 & 78.75 \\
\hline
\end{tabular}




\section{Chemical and microbial properties of soil}

Data with respect to chemical and microbial properties of soil in organic and inorganic treatments after harvest of the crop are presented in table 3 . From the data it can be seen that in general the association of organic manure has resulted in marginal increase in soil $\mathrm{pH}$ and reduction in electrical conductivity. There was substantial improvement in organic carbon content and the values were markedly higher in all organic treatments as compared to inorganic treatments, which are in accordance with the findings of Saha et al., (2010). The data on soil respiration and dehydrogenase activity, the indicators of microbial population and their activity clearly suggests that substantial increase in microbial population in all organic treatments as compared to inorganic treatments and also among organic treatments the activity was marginally more with increased amount of farm yard manure application. These are in agreement with findings of Krishnakumar et al., (2005) and Chang et al., (2007).

Thus, from this study it can be concluded that onion crop can be successfully produced organically by adopting appropriate organic farming protocols with more emphasis on good organic nutrient supply system adopting enrichment of manures using bio-fertilizers and bio-pesticides. The results also have shown positive aspects of organic farming practices through improvement in storage life of onion bulbs and enhanced soil microbial population and their activities.

\section{References}

Chang, E. H., Chung, R. S. and Tsai, Y. H. 2007. Effect of different application rates of organic fertilizer on soil enzyme activity and microbial population. Soil Sci. and Plant Nutri, 53:132-140.
Gomez, K. A. and Gomez, A. A. 1983. Statistical Procedure for Agricultural Research. Second edition. WileyInternational Science Publication. New York, United States of America.

Krishnakumar, S., Saravanan, A., Natarajan, S. K., Veerabadran, V. and Mani, S. 2005. Microbial population and enzymatic activity as influenced by organic farming. Res. J. Agric. Biol. Sci., 1 (1): 85-88.

Lal, S., Yadav, C., Mangal, J. L., Avtar Singh and Batra, V. K. 2002. Effect of FYM and irrigation levels on growth and yield of onion cv-Hisar-2. Haryana $J$. Hort. Sci., 31:256-258.

Mamatha, H. N. 2006. Effect of organic and inorganic sources of nitrogen on yield and quality of onion (Allium cepa L.) and soil properties in Alfisols. M.Sc. (Agri.) Thesis, Univ. Agric. Sci., Dharwad, Karnataka (India).

National Horticulture Board. (2014). Indian Horticulture Database. Ministry of Agriculture, Government of India.

Prabhakar, M., Hebbar, S. S. and Nair, A. K. 2012. Effect of organic farming practices on growth, yield and quality of rose onion (Allium cepa). Ind. J. Agril. Sci., 82 (6): 500-503.

Pradeep, G. and Sharanappa. 2014. Effect of organic farming practices on growth, yield, quality and economics of onion (Allium cepa) in dry zone of Karnataka. Ind. J. Agron., 59 (2): 336-340.

Saha, R., Nath, V. and Kumar, D. 2010. Effects of farmyard manure on soil organic carbon stock, the pattern of fertility build-up, and plant growth in 'Mallika' mango (Mangifera indica L.). J. Horti. Sci. Biotech., 85(6): 539-543.

Sofia, P. K., Prasad, R. and Vijay, V. K. 2006. Organic farming tradition reinvented. Ind. J. Traditional Knowledge, 5 (1): 139-142.

Sridhar, K., Rajesh, V., Omprakash, S., 
Prathyusha, C. and Suneetha, K.B. 2014. A critical review on organic farming of vegetables. Int. J. App. Bio. And Pharmaceutical Tech., 5 (1): 216221.

Yadav, S.K., Subhash, B., Yadav, M.K. and Suresh, P. 2013. Review of Organic
Farming for Sustainable Agriculture in Northern India. Int. J. Agron., 1-8. Yassen A.A. and Khalid, K.A. (2009). Influence of organic fertilizers on the yield, essential oil and mineral content of onion. Int. Agrophysics, 23: 183-188.

\section{How to cite this article:}

Prabhakar, M., S.S. Hebbar, A.K. Nair, P. Panneer Selvam, R.S. Rajeshwari and Praveen Kumar. 2017. Growth, Yield and Quality of Onion (Allium Cepa L.) as Influenced by Organic Farming Practices. Int.J.Curr.Microbiol.App.Sci. 6(8): 144-149. doi: https://doi.org/10.20546/ijcmas.2017.608.020 